\title{
Duration of Protection against Vibriosis in Ayu Plecoglossus altivelis Vaccinated by Immersion and Oral Administration with Vibrio anguillarum
}

\author{
Katsuhiko KaWANO,* Takashi AOKI,* and Tadatoshi KITAO* \\ (Accepted September 1, 1983)
}

\begin{abstract}
Excellent protection against vibriosis was provided to ayu Plecoglossus altivelis vaccinated by immersion with $5.32 \% \mathrm{NaCl}$ solution containing either 0.94 (wet) $\mathrm{g} / l$ or 9.4 (wet) $\mathrm{g} / l$ of lyophilized cells of Vibrio anguillarum. The duration of protective immunity in fish was at least 113 days. A high level of protection against vibriosis was also demonstrated in fish orally vaccinated with bacterin administered at a rate of 0.4 (wet) $\mathrm{g} / \mathrm{kg}$ fish/day for 15 days. However, this protective immunity lasted only 50 days after the first administration of vaccine. The serum from fish which had been vaccinated by either the immersion or oral administration did not show detectable levels of agglutinating antibodies against $V$. anguillarum.
\end{abstract}

Vaccination by the immersion method has been shown to provide adequate protective immunity against vibriosis, ${ }^{1)}$ red mouth disease, ${ }^{2)}$ pasteurellosis, ${ }^{3)}$ and edwardsiellosis. ${ }^{4)}$ In order to improve the immersion vaccine against vibriosis, we modified the immersion method from one consisting of formalin-killed Vibrio anguillarum in culture broth to a washed lyophilized cell suspension. ${ }^{5}$. This modification removed the exotoxins present in the culture broth from the vaccine. Moreover, a high level of protection against vibriosis was obtained when ayu Plecoglossus altivelis were immersed in a $5.32 \% \mathrm{NaCl}$ solution before exposure to the lyophilized cells of $V$, anguillarum. This improved method is simple, safe, and easily allows large numbers of fish to be treated at the same time. We also developed a water-borne hyperosmotic challenge method in which fish were reproducibly infected with $V$. anguillarum cells. ${ }^{\theta}$ This challenge method clearly demonstrated the differences in mortality between vaccinated and non-vaccinated fish.

Another simple method for the delivery of bacterins to large numbers of fish is oral vaccination. ? Excellent protection has been shown to be provided against vibriosis in ayu immunized by the oral vaccination method. ${ }^{8)}$

In the present study, the duration of protective immunity in ayu vaccinated by our modified immersion method using 2 concentrations of lyophilized cells is compared with that obtained by oral administration. The duration of protective immunity is also compared for immersion-vaccinated fish maintained at 2 different water temperatures.

\section{Materials and Methods}

\section{Vaccination of Fish}

The mean body weight of ayu collected from the freshwater Lake Biwa was $15 \mathrm{~g}$ at the time of vaccination. A total of 400 fish were immersed for $3 \mathrm{~min}$ in a $5.32 \% \mathrm{NaCl}$ solution containing 9.4 (wet) $g / l$ polyvalent vaccine with formalinkilled cells of $V$. anguillarum PT24 (serotype A), ${ }^{\text {) }}$ PT496 (serotype B), and PT213 (serotype C) (wet $1 \mathrm{~g}$ : about $10^{9}$ cells) (supplied by Kitasato Institute) (Group I). The immersed fish were reared in underground water at about $20^{\circ} \mathrm{C}$.

A total of 800 fish were also immersed for $3 \mathrm{~min}$ in a $5.32 \% \mathrm{NaCl}$ solution containing 0.94 (wet)g/l of the same polyvalent vaccine. After immersion the fish were divided into two groups with one group of 400 fish being reared in a tank with underground water at $20^{\circ} \mathrm{C}$ (Group II), and another group of 400 fish being reared in a tank with water

* Department of Fisheries, Faculty of Agriculture, Miyazaki University, Miyazaki 880, Japan（河野勝彦 青木 宙・北尾忠利：宮崎大学農学部)。

Present address of K. Kawano: Central Laboratories, Kyoritsu Shoji Co Ltd., Inashiki, Ibaragi 300-12, Japan.

Correspondence: T. Aoki, Department of Fisheries, Faculty of Agriculture, Miyazaki University, Miyazaki 880, Japan. 
Table 1. Duration of protective immunity in fish vaccinated by immersion or oral routes

\begin{tabular}{|c|c|c|c|c|c|c|c|c|c|c|c|}
\hline \multirow{2}{*}{ Group } & \multirow{2}{*}{ Vaccination method } & \multirow{2}{*}{$\begin{array}{l}\text { Reared in } \\
\text { water supplied } \\
\text { from }\end{array}$} & \multirow{2}{*}{$\begin{array}{c}\text { Challenge } \\
\text { levels } \\
\text { (cells } / \mathrm{m} l \text { ) }\end{array}$} & \multicolumn{8}{|c|}{ Days after vaccination } \\
\hline & & & & 1 & 10 & 20 & 30 & 40 & 50 & 60 & 113 \\
\hline \multirow[t]{2}{*}{ I. } & Immersion in 9.4 (wet)g/l & Underground & $10^{\circ}$ & $100^{* 1}$ & 0 & 0 & 0 & 0 & 0 & 0 & 0 \\
\hline & lyophilized cells & & $10^{8}$ & 90 & 20 & 0 & 0 & 10 & 10 & 30 & 50 \\
\hline \multirow[t]{2}{*}{ II. } & Immersion in 0.94 (wet)g/l & Underground & $10^{5}$ & 40 & 10 & 0 & 0 & 0 & 0 & 10 & 0 \\
\hline & lyophilized cells & & $10^{6}$ & 100 & 60 & 0 & 30 & 0 & 50 & 70 & 30 \\
\hline \multirow[t]{2}{*}{ III. } & Immersion in 0.94 (wet)g/l & Freshwater & $10^{5}$ & 80 & 0 & $\mathbf{0}$ & 0 & 0 & 0 & 0 & 14 \\
\hline & lyophilized cells & Lake Biwa & $10^{8}$ & 90 & 30 & 0 & 30 & 10 & 30 & 60 & 29 \\
\hline \multirow[t]{2}{*}{ IV. } & Oral administration with & Underground & $10^{5}$ & 50 & 80 & 0 & 0 & 0 & 10 & 50 & $\mathrm{NT}^{* 2}$ \\
\hline & $\begin{array}{l}0.4 \text { (wet)g/ } / \mathrm{kg} \text { fish/day for } \\
15 \text { days }\end{array}$ & & $16^{6}$ & 80 & 100 & 50 & 60 & 10 & 60 & 100 & NT \\
\hline \multirow[t]{2}{*}{ V. } & Non-vaccination & Underground & $10^{5}$ & 60 & 703 & 30 & 50 & 0 & 30 & 100 & 80 \\
\hline & & & $10^{6}$ & 100 & 1008 & 80 & 80 & 50 & 100 & 90 & 90 \\
\hline
\end{tabular}

*1 Mortality rate $(\%$ was observed 10 days after challenge. *2 Not tested.

The temperature of the underground water supply was $20^{\circ} \mathrm{C}$ for 20 days falling gradually to $18^{\circ} \mathrm{C}$ by 113 days after vaccination. Lake Biwa water was $25^{\circ} \mathrm{C}$ for 20 days and fell gradually at $12^{\circ} \mathrm{C}$ by 113 days after vaccination. The mean temperature of these water supplied was $19.4^{\circ} \mathrm{C}$ and $21.4^{\circ}$, respectively. Days after oral vaccination were counted from first administration.

supplied from Lake Biwa (Group III).

The same number of fish were fed with commercial pellets soaked with the polyvalent bacterin. The bacterin was administered to 0.4 (wet) $\mathrm{g} / \mathrm{kg}$ fish/day for 15 days. After vaccination Group IV fish were reared in a tank with underground water. As a control the same number of fish were immersed for $3 \mathrm{~min}$ in a $5.32 \% \mathrm{NaCl}$ solution and then reared in underground water (Group V). All fish were fed daily with commercial pellets until challenge. All the experimental group fish were illuminated from 4:00 to 11:00 PM to inhibit their maturation.

\section{Challenge of Fish}

A total of 20 fish from Group I to V were challenged at $1,10,20,30,40,50,60$, and 113 days after vaccination. Both the immersion vaccinated and the control fish were challenged by the water-borne hyperosmotic method in which fish were exposed to a $5.32 \% \mathrm{NaCl}$ solution followed by a suspension containing $10^{5}$ or $10^{6}$ cells $/ \mathrm{m} l$ of $V$. anguillarum SG7754 $4^{6)}$. This challenged strain was maintained at high virulence by passaging through ayu for the duration of the challenge period. Orally vaccinated fish in Group IV were also challenged by this water-borne method at $1,10,20,30,40,50$, and 60 days after the start of oral vaccine administration. Mortalities in the challenged fish were then observed for 10 days.

\section{Agglutinating Antibodies in Fish Sera}

Serum was collected from 10 fish in each of
Group I to V by severing the caudal artery. The serum agglutinating titer to $V$. anguillarum in the pooled sera was determined using the microtiter method. ${ }^{9)}$

\section{Results}

The mean water temperature in the tanks with underground water and with Lake Biwa freshwater were $19.4^{\circ} \mathrm{C}$ and $21.4^{\circ} \mathrm{C}$, respectively, for the rearing period. However, the temperature of the underground water supply was $20^{\circ} \mathrm{C}$ for 20 days falling gradually to $18^{\circ} \mathrm{C}$ by 113 days after vaccination. Lake Biwa water was $25^{\circ} \mathrm{C}$ for 20 days and fell gradually to $12^{\circ} \mathrm{C}$ by 113 days after vaccination.

The mortality rate among challenged fish in Groups I and II which had been vaccinated by immersion in 9.4 (wet)g/l and 0.94 (wet)g/l of lyophilized cells, respectively, are shown in Table 1. There was no protection against vibriosis in those fish vaccinated by immersion one day after vaccination, but protective immunity began to appear 10 days after vaccination. At 10 days post vaccination, mortality rates of $10 \%$ and $60 \%$ were achieved when Group II was challenged with $10^{5}$ and $10^{8}$ viable cells $/ \mathrm{ml}$ of $V$. anguillarum, respectively. These values were higher than those obtained when fish immersed in a 10-times higher level of lyophilized cells were subjected to the same challenge. Thereafter, the mortality rates were not different between Group I and II. The mortality rates in these immersed fish $20,30,40,50,60$, and 113 days post vaccination were significantly 
Table 2. Agglutinating antibodies of fish serum in either immersion or oral routes

\begin{tabular}{|c|c|c|c|c|c|c|c|c|c|c|}
\hline \multirow{2}{*}{ Group } & \multirow{2}{*}{ Vaccination method } & \multirow{2}{*}{$\begin{array}{l}\text { Reared in } \\
\text { water supplied } \\
\text { from }\end{array}$} & \multicolumn{8}{|c|}{ Days after vaccination } \\
\hline & & & 1 & 10 & 20 & 30 & 40 & 50 & 60 & 113 \\
\hline I. & $\begin{array}{l}\text { Immersion in } 9.4 \text { (wet)g/l } \\
\text { lyophilized cells }\end{array}$ & Underground & $<4^{* 1}$ & $<4$ & $<4$ & $<4$ & $<4$ & $<4$ & $<4$ & $<4$ \\
\hline II. & $\begin{array}{l}\text { Immersion in } 0.94 \text { (wet)g/l } \\
\text { lyophilized cells }\end{array}$ & Underground & $<4$ & $<4$ & $<4$ & $<4$ & $<4$ & $<4$ & $<4$ & $<4$ \\
\hline III. & $\begin{array}{l}\text { Immersion in } 0.94 \text { (wet)g/l } \\
\text { lyophilized cells }\end{array}$ & $\begin{array}{l}\text { Freshwater } \\
\text { Lake Biwa }\end{array}$ & $<4$ & $<4$ & $<4$ & $<4$ & $<4$ & $<4$ & $<4$ & $<4$ \\
\hline IV. & $\begin{array}{l}\text { Oral administration with } \\
0.4 \text { (wet)g/kg fish } / \text { day for } \\
15 \text { days }\end{array}$ & Underground & $<4$ & $<4$ & $<4$ & $<4$ & $<4$ & $<4$ & $<4$ & $\mathbf{N T}^{* 2}$ \\
\hline v. & Non-vaccination & Underground & $<4$ & $<4$ & $<4$ & $<4$ & $<4$ & $<4$ & $<4$ & $<4$ \\
\hline
\end{tabular}

lower than those obtained for challenged nonvaccinated fish. The duration of protective immunity of these immersion vaccianted fish lasted for at least 113 days after vaccination.

The protective immunity seen in fish belonging to Group III 10 days post vaccination and maintained in $25^{\circ} \mathrm{C}$ water was much higher than for fish in underground water at $20^{\circ} \mathrm{C}$. However, no differences were seen in protective immunity in fish held in either kind of water supply 113 days post vaccination (Table 1). The immersed fish in Group I, II, and III 113 days after vaccination had a mean weight of $34.5 \mathrm{~g}$.

Protcetion appeared in orally vaccinated fish 20 days after the first administration of the vaccine ( 5 days after the final administration of the vaccine) (Table 1). The protective immunity continued for 50 days in orally vaccinated fish. However, after 60 days no differences in mortality were observed between vaccinated fish and controls.

The mortality rates of fish in Groups I, II, III, and IV, which were challenged with $10^{5} \mathrm{cells} / \mathrm{m} l$ of $V$. anguillarum, were lower than those challenged with $10^{8} \mathrm{cells} / \mathrm{m} l$ for any period except for Day 1 of Group I.

The agglutinating antibody titers of fish in Groups I, II, III, and IV immersed in lyophilized cells were not different from those of control fish when immersed at $1,10,20,40,40,50,60$, and 113 days after vaccination (Table 2). Fish which were orally immunized did not show detectable levels of agglutinating antibodies.

\section{Discussion}

Immersion of ayu in a $\mathrm{NaCl}$ solution containing 9.4 (wet)g/l or 0.94 (wet)g/l polyvalent bacterin with lyophilized cells of $V$. anguillarum resulted in a high level of protection against vibriosis. The duration of protective immunity in these fish vaccinated by immersion lasted 113 days post vaccination. JoHNSON et al. ${ }^{10)}$ indicated that the duration of protective immunity conferred by immersion vaccination varied with the species of salmonid and the size of the fish. Coho salmon Oncorhynchus kisutch (body weight of $1.4 \mathrm{~g}$ ) had greater immunity and were provided with protection against vibriosis for a year or longer. We did not bother to check for protection against vibriosis in immersion vaccinated fish more than 113 days after vaccination because ayu fry grow to commercial size in 3 months. Certainly it apperas that protective immunity can be maintained in cultured ayu for this 3-month period.

Although protective immunity was not seen 1 day post vaccination, the onset of protective immunity seemed to appear within 10 days. Our results show a high level of protective immunity in ayu immersed in 0.94 (wet)g/l. Since ANTIPA et al. ${ }^{11)}$ observed a high level of protection in sockeye salmon $O$. nerka immersed by the hyperosmotic infiltration method in bacterin containing $2 \times 10^{7}$ cells $/ \mathrm{m} l$ and $2 \times 10^{4}$ cells $/ \mathrm{m} l$ of $V$. anguillarum, it seems likely that we also can reduce the bacterial cell numbers in our bacterin and still provide a high level of protection. Further research is clearly needed to determine accurately the onset of protective immunity, the minimum size of fish, and the minimal concentration of bacterial cells which confer protection by our modified immersion method.

The temperature of water supplied from Lake Biwa stayed at $25^{\circ} \mathrm{C}$ for 20 days after immersion vaccination. Thereafter, the water temperature fell gradually to $12^{\circ} \mathrm{C}$ by 113 days after vaccina- 
tion. The water temperature supplied from Lake Biwa differed by about $5^{\circ} \mathrm{C}$ from that of the underground water for 20 days after vaccination. Protective immunity in immersed fish held at $25^{\circ} \mathrm{C}$ was better than that of those held at $20^{\circ} \mathrm{C} 10$ days post vaccination. However, protective immunity was not different for either temperature 20 days after vaccination. The fish maintained their protective immunity against vibriosis for 113 days in spite of the falling water temperatures. Thus, fish can obtained protective immunity from a single immersion exposure, and this immunity can be maintained even though the water temperature falls below the optimum holding temperature.

A high degree of protection against vibriosis was demonstrated with both immersion and oral administration methods; however, the duration of protective immunity was longer by using immersion vaccination. Oral vaccination has other disadvantages such as the great need for the vaccine to exhibit a high efficacy, and the time wasted when preparing and using the bacterin-containing pellets. Mass immunization of ayu against vibriosis using immersion procedures appears to be practical. Large numbers of ayu can be immunized quickly and simply by this method. The present study indicated its pratical applicability to ayu culturing.

No protection of agglutinating antibodies against $V$. anguillarum was found in the serum of fish vaccinated by the immersion method. This contrasts with another researcher who have reported that antibodies were detectable in the serum of the immersed fish. ${ }^{12}$ However, humoral antibodies are not thought to play a role in the prevention of vibriosis. Cellular immunity may paly a more important role. Research on this aspect will be reported in the near future.

\section{Acknowledgements}

We wish to thank Dr. S. TAKAHASH of Shiga Prefectural Fisheries Experimental Station for his professional and techinical help. Shiga Prefectural Fisheries Experimental Station kindly allowed us the use of their facilities and expertise. This research was supported in part by a grant-in-aid for Scientific Research from the Ministry of Education, Science and Culture of Japan.

\section{References}

1) T. Aoki, T. Kitao, M. Fukudome, S. Takahasi, and S. EguSA: Bull. Fac. Agri. Miyazaki Univ, 29, 77-85 (1982).

2) D.P. ANDERSON, B.S. RoBERSON, and O.W. Drxon: J. Fish Biol., 15, 317-322 (1979).

3) Y. FUKUdA and R. KUSUdA: Bull. Japan. Soc. Sci. Fish., 47, 147-150 (1981).

4) Y.L. Song and G.H. Kov: Fish Pathol. 15, 249-255 (1981).

5) T. Aoki, T. Kitao, M. Fukudome, S. TAKahashi, and S. Egusa: J. Fish Disease., 7, 149-156 (1984).

6) K. Kawano, T. Aoki, and T. Kitao: Fish Pathol., 18, 143-149 (1983).

7) J. L. Fryer, J. S. Rohovec, G. L. Tebit, J. S. MCMichael, and K.S. PILCHER: Fish Pathal., 10, 155-164 (1976).

8) R. Kusuda, K. Kawai, Y. Jo, T. AKIzUKI, M. FukUNAGA, and N. Kotake: Bull. Japan. Soc. Sci. Fish., 44, 21-25 (1978).

9) T. Kitao, T. Aoki, M. Fukudome, K. Kawano, Yo, WADA, and Y. Mizuno: J. Fish Disease, 6, 175-181 (1983).

10) K. A. Johnson, J. K. Flynn, and D. F. Amend: J. Fish Disease., 5, 207-213 (1982).

11) R. ANTIPA, R. Gould, and D. F. AMEnd: $J$. Fish Disease., 3, 161-165 (1980).

12) R. ANTIPA and D. F. AMEND: J. Fish Res. Board Can. 34, 203-208 (1977). 